\title{
THE EDUCATION SYSTEM IN ROMANIA TODAY
}

\author{
Anca ŞTEFĂNESCU ${ }^{184}$
}

Motto: Education is the most powerful weapon you can use to change the world (Nelson Mandela)

\begin{abstract}
Romanian education is a great system that carries out a complex but extremely important process for our society. It seems to work but there is a lot to change even where things are seemingly going well. A complete analysis brings to our attention a tumultuous picture of the problems faced by education in Romania in an attempt to fully fulfill the social objective it has assumed. Education is changing with the evolution of technologies, society is changing every day, the global economy needs other skills and the world now needs much more complex things than 20 years ago.

The question is, how can education be changed quickly and effectively? In general, the change in education is very difficult, but in order to complete such a process, a real and concrete analysis of what we have now is needed.
\end{abstract}

Keywords: Romania, education, sistem, skills, economy, educational reforms, Bologna Process, academic mobility, institutional autonomy

\section{BRIEF HISTORY OF ROMANIAN EDUCATION}

In the 19th century well-known pedagogues of the period - Pestalozzi and Froebel - were concerned with the practical and theoretical aspects of the education system and Froebel (1782-1852), the first German theorist of preschool education, believed that children are born with creative skills innate, and schools have a role to play in enhancing these native creative skills. These pedagogical theories also influenced the development of the Romanian school system. The education system in Romania was punctuated by major educational reforms that marked its evolution and can be structured in distinct periods of convergence (late eighteenth century - pre-World War II, 1968-1969 and 1989-present) and divergence (mostly of the communist regime) with and from the educational system from Western Europe.

Education experts in the twentieth century continued the changes produced in the nineteenth century in Romania. I would mention here some of the great contributors to the modernization of the Romanian education system in the 20th century: Constantin Dumitrescu Iași (1849-1923) and Spiru Haret (1851-1923). It

184 “Alexandru cel Bun” Military Academy - Chișinău, Doctoral school. 
is well known that Iasi and Haret laid the foundations of the modern Romanian educational system. The former, educated at the Sorbonne University, where he received his doctorate in mathematics, Minister of Education in three different stages (1897-1899; 1901-1904; 1907-1910), adopted educational reforms for the primary, secondary and tertiary levels. Spiru Haret adopted the Education Law of 1868, which established the basis of vocational schools and reorganized the secondary education system and Constantin Dumitrescu Iasi, together with Spiru Haret reorganized the university education system and they also divided high schools, or high schools, into specialties such as realistic, modern, and classical high schools, or high-profile, modern, and classic high schools ${ }^{185}$.

The essential features of communist-era education were "extreme centralization with a single basic and manual curriculum, excessive politicization, and emphasis on the abstract and the theoretical in method and teaching." ${ }^{186}$ After the collapse of the communist regime, the higher education system oscillated between centralism and autonomy, now finding itself in a stage with a special emphasis on institutional autonomy, quality assurance and the social dimension.

The social, political and economic transformations in Romania registered after 1989, to which are added the pressures for a rapid and major transformation of the society, led to a reform of the educational system which was characterized in 1999 as bearing "traces of 18th century romanticism 19th century, positivism of the 19th century, Eastern European socialism and disorganized efforts to bring about change after $1989 " .187$

Since 1999, the Romanian education system has adopted the reforms in Bologna that produced a small "revolution" by drafting new legislation in the field of education, legislation designed to adapt to the changes brought by the ministerial meetings of the Bologna Process. The objective of creating a higher education policy at EU level and a field of dialogue materialized in 1999, when the Bologna Declaration was signed and the reforms set out here aim at creating a knowledge-based economy and an informed workforce. "The transition to an educational model oriented towards the needs of the free market was observed after the adoption of the Bologna Process". 188

A new wave of changes at university level was brought about by the Bologna reforms that began in 2004 when the Romanian Parliament adopted the Law on the structure of university studies when the three-tier system replaced the two-tier system originally mandated by the Bologna Declaration of 1999.

\footnotetext{
${ }^{185}$ Ion Gh. Stanciu, Romanian pedagogy in the 20th century, Didactic and Pedagogical Publishing House, Bucharest, 1981. p. 194.

${ }^{186}$ Nedelcu, I. Fundamentals of intercultural education. Diversity, minorities, equity, Polirom Publishing House, 2008, p. 101.

${ }^{187}$ Marga, A. - Education in transition, Dacia-Bucharest Publishing House, 1999, p. 131.

${ }_{188}$ Dobbins M., Higher Education Policies in Central and Eastern Europe. Convergence towards a Common Model, Basingstoke 2011:Pallgrave Macmillan, p. 249.
} 
A new law with a special impact on the modernization of education in Romania was adopted in February 2011 and aims to diversify the mission of universities.

We can say that the evolution of education in Romania has brought the system to a legislative convergence and principles with what is currently developing in the European Union and now we are in a time of great social transformations with major effects on education and its objectives.

\section{MAIN CHARACTERISTICS OF THE EDUCATIONAL SYSTEM IN ROMANIA}

Romania is one of the countries with rapid economic growth. It has made significant progress in strengthening its democratic processes, in adapting economically to the principles of the European Union and in developing and adapting socially to the unprecedented technological development we are going through at this stage. There has also been great progress in modernizing its education system and increasing the level of learning of students.

However, the results obtained at the end of each educational cycle indicate that many Romanian children do not reach their potential to allow them to develop fully in accordance with current requirements. Many young Romanians leave education much too early and without mastering the basic skills for life and work.

Another part of those who go through the educational stages are deprived of the skills they need in a fast economy, under the impact of developments in technology, robotics, vertical agriculture or artificial intelligence. We can say that all these bring with them a profound transformation of the number, types and characteristics of jobs for which Romanian education graduates must be prepared.

The Romanian education system is structured horizontally and vertically and all responsibilities for the strategy, policy and implementation of education are concentrated within the Ministry of National Education. Of course, there are a number of external organizations that advise the ministry, but they play a very small role in the design and implementation of educational policies. The Ministry of National Education directly leads and monitors the implementation of national policies at the local level through the County School Inspectorates. And this is because the ministry is responsible for establishing the overall strategy of the education system and national policies, from pre-school and compulsory education to education and training and higher education.

The Ministry of National Education is responsible for the national evaluation system organized at the system level but the policy evaluation is done by specialized public bodies that are affiliated to the ministry or are in its coordination. For example, the technical expertise provided by the Institute of Long-Term Education Sciences (IES) is embodied in educational research and analyzes of the performances of the Romanian education system. IES also coordinates the development of Romania's new curriculum. 
If we refer to the National Center for Assessment and Examinations (NCAE) it designs and manages national examinations and assessments of students, establishes examinations for permanent teacher certification (finalized) and teacher tenure (tenure) and organizes the evaluation process of textbooks.

We can say that the presence of a separate examination and evaluation agency, an educational research institute and an external school inspectorate are elements that support an independent analysis of the field to support the continuous modernization of Romanian education. However, these bodies remain subordinate to the Ministry of Education.

The exceptions could be ARACIP ${ }^{189}$ and ARACIS ${ }^{190}$, structures that set their own strategies, work schedules and operating budgets. But even in their case, the government and the ministry make decisions about the structure and functioning model of the organization, which limits their ability to develop their professional independence.

In conclusion we can say that the Ministry of National Education organizes and leads the national system of education, training, scientific research, technological development and innovation and has as partners subordinate institutions and coordinated institutions.

The education system in Romania includes pre-university, university education and postgraduate studies. Pre-university education is an integral part of the national education set up as a system and brings together state, private and denominational education units, authorized or accredited. In Romania, there are public or private schools, in a system of educational alternative, which complete the classical education system, opening new perspectives of didactic and pedagogical approach to learning. The forms of organization of pre-university education are full-time education and part-time education.

Higher education is organized in universities, study academies, institutes, higher education schools that have obtained temporary operation authorization or accreditation. Higher education institutions can be state, private or denominational.

Bachelor's degree programs represent the first cycle of university studies and correspond to a minimum of 180 and a maximum of 240 transferable study credits, master's degree programs represent the second cycle of university studies and correspond to a minimum number of credits transferable studies, between 60 and 120 and doctoral studies represent the third cycle of university studies. The

\footnotetext{
189 Romanian Agency for Quality Assurance in Pre-University Education - performs external evaluation of the quality of education provided by pre-university education institutions and other organizations providing education, as well as authorization, accreditation and periodic evaluation of pre-university education units, https://www.edu.ro/ARACIP, accessed at 05 June 2021.

${ }^{190}$ Romanian Agency for Quality Assurance in Higher Education - carried out external evaluation of the quality of education offered by higher education institutions and other organizations providing curricula specific to higher education, operating in Romania. She is a full member of the European Association for Quality Assurance in Higher Education - ENQA and is registered in the European Register for Quality Assurance in Higher Education - EQAR, https://www.edu.ro/ARACIP available at 05June 2021, accessed at 05 June 2021.
} 
postgraduate programs are structured in postdoctoral programs of advanced research, postgraduate programs of training and continuous professional development and postgraduate programs of improvement Romania's public expenditures for education.

The development and modernization of education has led to an increase in the resources allocated to it in all countries. Their growth is due to the combined action of several factors such as population growth - which naturally led to an increase in the school population, economic development - which required a medium and higher skilled workforce, school policy, the principles considered by governments in setting educational policies, the level of compulsory education, etc. The financing of education is made according to its structure and the education systems are different from one country to another depending on tradition, economic and social needs.

The education system mobilizes considerable material and human resources and thus financial resources. These resources are provided in most cases to educational institutions by public authorities, but also by families, communities, companies and cooperation agencies. Sources of funding for education spending are diverse but the state budget which is the main source of funding for education in all countries of the world. In developed countries, education expenditures represent between $11 \%$ - $29 \%$ of total socio-cultural expenditures. In relation to total public spending, "education spending is between 7\% in the UK and $18 \%$ in the US and in developing countries between 14\% in the Czech Republic and 19\% Philippines." 191

The highest percentage of government spending on education was in Sweden and Denmark, 6.8\% and 6.5\%, respectively. Romania is part of a group of 6 states with expenditures below 4\% of GDP, consisting of Greece, Italy, Slovakia, Bulgaria and Ireland, being the last in this group and in the European Union. The year 2017 is the most recent for which there are data in Eurostat statistics. In 2018, education had funds of 29.3 billion lei, representing $3.1 \%$ of GDP, and in 2019, the allocation, after budget rectification, was 38.2 billion lei, ie $3.6 \%$ of GDP. ${ }^{192}$

If we study the Monitor of education and training 2019- ROMANIA we notice that the investments in education in Romania are constantly lower than the average registered in the European Union. If we study the Monitor of education and training 2019- ROMANIA we notice that the investments in education are constantly lower than the average registered in the European Union. It turns out that public spending on education, analyzed as a percentage of GDP, is $3.8 \%$ in 2009 compared to $5.2 \%$ in the EU. Later, in 2018, spending in Romania

\footnotetext{
191 Info administration, https://administrare.info/11-domenii/economie/17304-cheltuieli-publice-pentru\%C3\%AEnv\%C4\%83\%C5\%A3\%C4\%83m\%C3\%A2nt accessed at 25.05. 2021

192 Eurostat: Romania has the lowest government expenditure on Education in the European Union, https://www.google.com/search?client=firefox-b-d\&q=Eurostat\%3A+Romania+has+the+lowest+ government+expenditure+on+Education+in+the+European+Union accessed in 25.05.2021.
} 
stands at 2.8\% (€ 2094) compared to 4.6\% (€ 6,111), a percentage that we find at the EU average. ${ }^{193}$

In the period 2014-2020, approximately EUR 350 million was allocated from the European Regional Development Fund for investments in educational infrastructure in Romania, so it can be stated that EU Funds have constantly supported the modernization of educational infrastructure.

The financing of education in Romania is regulated by the National Education Law no. 1/2011, with subsequent amendments and completions. The financing from public funds of state higher education institutions is made from the budget of the Ministry of Education and has 3 main directions: basic, additional and complementary financing. All funds for basic and additional funding of state universities are considered own revenues.

The financing of state higher education institutions is made on the basis of a contract concluded between the Ministry of Education and the respective higher education institution and the rectors of state universities are directly responsible for the allocation of the institution's resources.

\section{CONCLUSIONS}

We analyzed at an extremely wide level the education in Romania today and we determined some of its most obvious characteristics. What needs to be added is the fact that education is changing with the development of technologies that today have an extremely fast pace of evolution.

Now the world needs much more complex things than 20 years ago and adapting education to these requirements must be done as quickly as society transforms.

If in the past, success was given by those things that you could easily teach and test now, they are taken over by computers. The key to success in such a society lies in the ability to think complexly. and this is the fundamental challenge for education in Romania. Now you need to educate different skills through appropriate methods. However, change needs high-caliber teachers, who not only convey the generally recognized thinking of the moment, but also encourage young people to question it, to create and use new technologies in other ways of analysis.

But to improve the teaching profession means, on the one hand, to attract very good people to it and, on the other hand, to change and improve the performance of those who already work in the field. And this is because the enthusiasm of teachers is decisive in the way young people perceive their lives and school.

\footnotetext{
193 Education and training monitor 2019, Education and training Romania, https://ec.europa.eu/ education/sites/default/files/document-library-docs/et-monitor-report-2019-romania_ro.pdf, accessed at 25.05. 2021 .
} 


\section{BIBLIOGRAPHY}

- Dobbins M., Higher Education Policies in Central and Eastern Europe. Convergence towards a Common Model?, Basingstoke 2011: Pallgrave Macmillan.

- Marga A., Education in transition, Dacia-Bucharest Publishing House, 1999.

- Nedelcu I., Fundamentals of intercultural education. Diversity, minorities, equity, Polirom Publishing House, 2008.

- Stanciu I., Romanian pedagogy in the 20th century, Didactic and Pedagogical Publishing House, Bucharest, 1981.

- https://www.edu.ro/ARACIP

- https://www.aracis.ro/

- https://administrare.info/11-domenii/economie/17304-cheltuieli-publicepentru-\%C3\%AEnv\%C4\%83\%C5\%A3\%C4\%83m\%C3\%A2nt

- https://www.edu.ro/descriere

- https://edu.ro/tertiar-nonuniversitar

- http://legislatie.just.ro/Public/DetaliiDocumentAfis/215131

- https://ec.europa.eu/education/sites/default/files/document-library-docs/etmonitor-report-2019-romania_ro.pdf 